Крук Е.Г.

Повышение мотивации труда работников в транспортной компании

ФГБОУ ВО «Уральский Государственный Университет Путей Сообщения»

doi: $10.18411 / s r-10-04-2019-02$

idsp: sciencerussia-10-04-2019-02

Аннотация

В статье рассматриваются ключевые аспекты мотивации труда, а также возможность повышения мотивации труда в транспортной компании.

Ключевые слова: мотивация, труд, транспортная компания, рабочая сила.

Abstract

The article discusses the key aspects of motivation, as well as the possibility of increasing motivation in the transport company.

Key words: motivation, labour, transport company, labour force.

В настоящее время в развитии предпринимательства в России человеческие ресурсы являются самым главным фактором при достижении успеха в бизнесе. Зачастую руководители стараются создать благоприятные условия труда для своих подчиненных с помощью определенной мотивации. К такой мотивации относятся системы моральноматериального стимулирования, карьерного роста персонала и нематериальное стимулирование.

Под мотивацией персонала понимается комплекс материальных и нематериальных стимулов, которые обеспечивают качественный и производительный труд работников, помогают привлечь талантливых специалистов и возможность удержать их [1].

На предприятии работодатель вправе самостоятельно определить методы поощрений. При должном поощрении работник начинает получать удовольствие от работы и стремится как можно лучше выполнить поставленные цели и задачи, поэтому руководителю очень важно правильно выбрать систему мотивации, причем иногда к каждому работнику важен персональный подход.

Выбор предприятием той или иной формы (системы) оплаты труда зависит от многих факторов, но в любом случае в современных условиях выбранная система должна отражать стоящие перед ним стратегические цели, управленческую философию его руководителей, традиции, а также учитывать находящиеся в его распоряжении ресурсы и материальные интересы работников. Критерием правильности выбора системы оплаты труда, должна быть ее экономическая эффективность.

Рассмотрим виды мотивации персонала и представим их в таблице 1

Таблица 1

Видыл мотивачии

\begin{tabular}{|c|c|}
\hline Вид & Выражение \\
\hline \multicolumn{2}{|c|}{ Позитивная мотивация } \\
\hline Материальное денежное & $\begin{array}{l}\text { Различные надбавки, премии, оклады, доплаты и } \\
\text { прочие выплаты }\end{array}$ \\
\hline Материальное неденежное & $\begin{array}{l}\text { Абонементы, путевки, подарочные сертификаты, } \\
\text { компенсация мобильной связи, обучения и прочее }\end{array}$ \\
\hline Нематериальное поощрение & $\begin{array}{l}\text { - изменение рабочего графика в пользу } \\
\text { работника; } \\
\text { - церемонии награждения; } \\
\text { - дипломы, грамоты; } \\
\text { - улучшение рабочего места и др. }\end{array}$ \\
\hline \multicolumn{2}{|c|}{ Негативная мотивация } \\
\hline Санкции & $\begin{array}{l}\text { Штрафы, общественное осуждение, уголовная } \\
\text { ответственность и др. }\end{array}$ \\
\hline
\end{tabular}


Обычно материальное поощрение является самым ощутимым видом мотивации.

Также нематериальное поощрение можно разбить на следующие классификации представленные в таблице 2.

Для того чтобы нематериальное поощрение было успешным очень важно иметь открытые и доверительные отношения между руководством и подчиненными, а именно:

- точное и постоянное информирование о производственно-экономических ситуациях, которые складываются в компании;

- информирование об ожидаемых перспективах;

- информирование о намечаемых действиях;

- информирование об успешности и реализации компании;

\section{Таблища 2}

Виды нематериального поощрения

\begin{tabular}{|c|c|c|}
\hline Корпоративно-системные & Социально-психологические & Социально-бытовые \\
\hline $\begin{array}{l}\text { - организационные } \\
\text { - творческие } \\
\text { - стимулирование свободным } \\
\text { временем } \\
\text { - корпоративная культура } \\
\text { - продвижение по службе } \\
\text { - стимулирование обучением } \\
\text { - делегирование полномочий } \\
\text { - участие в акционерном капитале }\end{array}$ & $\begin{array}{l}\text { - признание (личная похвала, } \\
\text { общественное признание) } \\
-\quad \text { подарки за высокие } \\
\text { результаты работы и творческие } \\
\text { достижения } \\
-\quad \text { стимулирование } \\
\text { ответственностью } \\
\text { - возможность напрямую } \\
\text { обращаться к руководству } \\
\text { - комфортное рабочее место } \\
\text { - условия для релаксации }\end{array}$ & $\begin{array}{lc}\text { - } \quad \text { социальные } & \text { льготы, } \\
\text { предусмотренные } & \text { ТК } \\
\text { (жилье, } & \text { медицинское } \\
\text { обслуживание, } & \text { организация } \\
\text { питания, организация обучения } \\
\text { и воспитания детей и др. } \\
\text { - подарки на праздники и к дням } \\
\text { рождения и юбилеям } \\
\text { - гибкие социальные выплаты } \\
\text { (большие } \\
\text { непредусмотренные } \\
\text { законодательством) }\end{array}$ \\
\hline
\end{tabular}

Зачастую неожиданное поощрение мотивирует лучше, чем планируемые [2].

Любая мотивация персонала должна быть тщательно проработана и желательно для каждого сотрудника индивидуально, а именно:

- персонал должен испытывать радость от работы, отдаваться работе всей душой, отвечать за полученные результаты;

- дать возможность персоналу показать на что он способен, дать возможность самовыражения в профессиональной деятельности;

- персонал должен чувствовать, что работодатель прислушивается к их мнению, связанному с улучшением условий работы;

— дать возможность оценить свою значимость в коллективе;

- предоставить возможность персоналу поставить самим рабочую цель, ведь для самопоставленной цели персонал потратит больше энергии и приложит максимум усилий для её достижения;

- хороший персонал имеет право на материальное и моральное поощрение;

- любые изменения, связанные с работой персонала должны приниматься при участии самого персонала;

— дать возможность персоналу приобретать новые навыки и обучаться новому;

Разработаем классификацию поощрений, которая сможет правильно замотивировать персонал.

1. Какие либо ценные бумаги:

- деньги;

- путевки в отпуск, санатории и пр.;

- медицинское обслуживание и страховка;

- билеты в кино, театр, на спорт;

— частичная оплата детских садиков, школ; 
2. Продовольственные поощрения:

- оплата питания;

— продовольственные наборы;

- пикники;

— кофейные(чайные) паузы;

3. Предметы для личного пользования:

- авто от фирмы;

— возможность работы в личном кабинете;

— бытовые приборы (чайник, микроволновка, холодильник);

- обеспечение канцелярскими принадлежностями;

- памятные подарки;

4. Моральные знаки внимания:

- дружеское поздравление;

- упоминание успехов;

— признание в коллективе;

- награждение дипломом, грамотой или благодарностью;

5. Свобода:

- различная оплата труда;

- перерывы на работе;

— возможность сказать о недостатках в работе и найти способы их решения и др.;

Использование различных форм и методов стимулирования позволит сформировать руководству фирмы действенную мотивацию кадров к эффективной деятельности, что, в свою очередь, будет способствовать не только функционированию, но и развитию предприятия. Поэтому хозяйственная деятельность предприятия во многом зависит от правильной организации финансовой и управленческой работы на предприятии, ведь если дать персоналу то, в чем он нуждается, то и стремиться достижения успехов он будет намного качественнее, быстрее и эффективнее.

$$
* * *
$$

1. О.Е. Алехина. Управление персоналом. - М: Экономист, 2018

2. А.Я. Кибанов. Мотивация и стимулирование трудовой деятельности. - М: Инфра - М, 2017. 